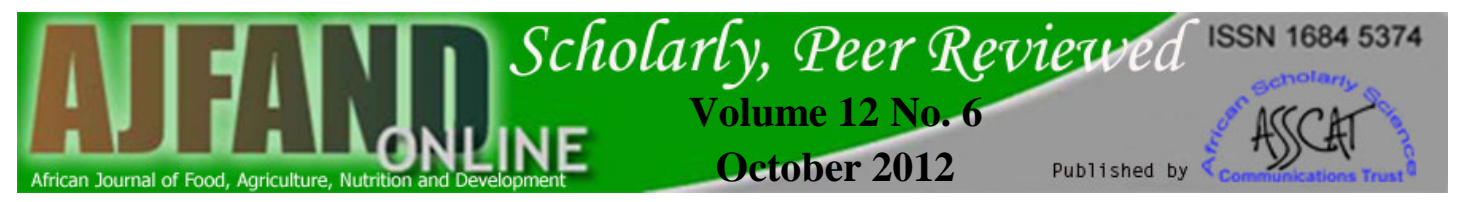

\title{
EFFECT OF TOMATO (Lycopersicon esculentum) POWDER ON OXIDATIVE STABILITY AND SENSORY CHARACTERISTICS OF BROILER MEAT
}

\section{Adeyemi $\mathrm{KD}^{1^{*}}$ and AO Olorunsanya ${ }^{2}$}

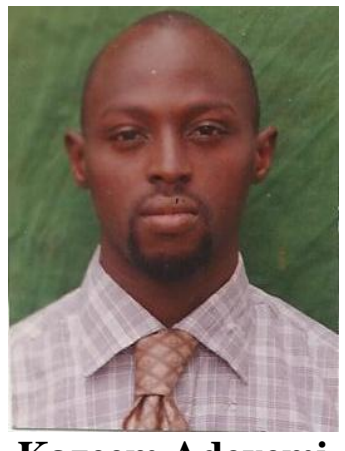

Kazeem Adeyemi

*Corresponding author's email: deyemy@yahoo.com

${ }^{1}$ Department of Animal Production, University of Ilorin, Ilorin, Nigeria

${ }^{2}$ Department of Animal Science, Ibrahim Badamosi Babangida University, Lapai, Niger State, Nigeria 


\section{ABSTRACT}

Antioxidant potency of graded levels of tomato powder in cooked and raw broiler meat under refrigerated storage was evaluated and compared with that of Butylated Hydroxyl Anisole (BHA), a synthetic antioxidant. To a separate 200g of minced broiler meat, $0 \%$ (control), $0.5 \%, 1 \%$ and $1.5 \%$ of tomato powder were applied. A positive control was prepared with $0.15 \%$ of BHA in a separate $200 \mathrm{~g}$ of minced broiler meat. Each sample was divided into 16 parts of $12.5 \mathrm{~g}$ each. Eight of these were cooked in a microwave oven for $1^{1 / 2}$ minutes while the other eight parts were left raw. The samples were packaged in different nylon bags, with labeling corresponding to the treatment applied and then stored in a refrigerator at $4^{0} \mathrm{C}$. Oxidative stability of the cooked samples was monitored for 6 days at two-day intervals while that of raw samples was monitored for 9 days at three-day intervals. A forty-member team was constituted to form the taste panel and was instructed on the parameters to adjudge using a five point Hedonic scale. The result showed that all additives and BHA reduced lipid oxidation in broiler meat. This was shown by lower TBARS values in meat samples with additives compared to meat samples without additive. There were significant differences $(\mathrm{P}<0.05)$ in the TBARS values of cooked and raw meat samples. There was a general increase in lipid oxidation as storage day progress. However, the increment was more pronounced in cooked meat samples than the raw meat samples. The result revealed that $0.5 \%$ and $1.5 \%$ tomato powder exhibited higher antioxidant potency $(\mathrm{P}<0.05)$ than BHA in the cooked and raw samples respectively. The control samples were the most susceptible to lipid oxidation. Sensory scores revealed that all levels of tomato powder improved the color, flavor, juiciness, tenderness and overall acceptability of broiler meat. Tomato powder could therefore, be used as a cheap, readily available and safe source of natural antioxidant to protect broiler meat from lipid oxidation and improve its sensory characteristics.

Key words: tomato, antioxidant, minced, broiler, BHA 


\section{INTRODUCTION}

Broiler meat is subject to chemical and microbial deterioration [1, 2]. Prominent among the chemical deteriorations, which this product is subject to, is lipid oxidation $[2,3,4]$. Lipid oxidation refers to the oxidative breakdown of polyunsaturated fatty acids, which causes off-color, off-odor and rancid taste or warmed over flavor thus lowering the quality of broiler meat [5, 6, 7]. Although, the major cause of lipid oxidation is oxidative breakdown of polyunsaturated fatty acids, changes in tissues can also occur because of reaction between protein and the products of oxidative processes [5, 7, 8]. Lipolytic enzymes such as lipases and phospholipases [9] also cause oxidative changes in fatty acids. The rate of lipid oxidation is influenced by light and temperature [10]. Lipid content and composition of poultry tissue vary considerably and directly influence the extent to which lipid oxidation develops during storage [8]. Age, sex and breed of animals are also known factors influencing the rate of lipid oxidation [5].

In order to prevent lipid oxidation, antioxidants are used [6, 7]. Based on their source, there are two types of antioxidants: synthetic and natural antioxidants [2, 11]. Synthetic antioxidants are obtained from inorganic chemicals or compounds. They have been in use for a fairly long period and are known to be effective [11, 12]. Examples are Butylated Hydroxyl Anisole (BHA), Butylated Hydroxyl Toluene (BHT), and Tertiary Butyl Hydroxyl Quinone (TBHQ) [2, 11]. Despite the effectiveness of these chemicals, there are some problems associated with their use. For instance, synthetic antioxidants are scarce, expensive and carcinogenic in nature $[11,12]$. Apart from causing cancer, they are said to cause diabetes, arteriosclerosis, impairment to blood clothing and lung damage [11, 13]. In the bid to find a lasting solution to these problems, it has been necessary to use natural antioxidants obtained from herbs and spices [4, 14], cereals and legumes [7, 14]. In recent years, increasing attention has been paid to the role of natural antioxidants in human health [15]. Such compounds, recognized as important factors in food preservation are now believed to be health-protecting factors $[10,15,16]$. In fact, they can act by reducing the content of toxic components in food and by supplying the human body with exogenous antioxidants $[10,15,17]$. For these reasons, information on the overall antioxidant properties of food is becoming relevant in the field of nutrition and food technology [18]. Thus, considering the important roles of these compounds in health protecting factors, the original antioxidant properties of food should be maintained using optimized food processing conditions $[10,16]$. It must, however, be stressed that the best way to lay an antioxidant rich foundation that is inhospitable to toxins and free radicals is through a combination of whole foods [15].

Tomatoes are fast becoming one of favorite foods, as they are a good source of antioxidants [19]. Apart from reducing lipid oxidation in oil and fatty foods, tomatoes can ward off certain kinds of cancer, prevent brain degeneration and cataracts, and help maintain mental function as humans age [15]. Tomatoes contain lycopene, a relatively rare member of the carotenoid family, also found in pink grape fruit and twice as powerful as beta-carotene [10]. Studies have shown that men who eat more tomatoes or tomato sauce have significantly lower rate of prostate cancer [15]. Other

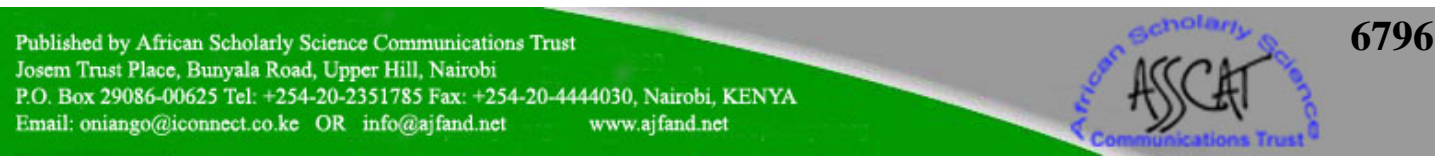


studies suggest that lycopene can help prevent lung, colon and breast cancer [11]. Tomatoes also contain glutathione, an antioxidant that helps boost immune functions $[10,15]$. In this light, this study was aimed at revealing the antioxidant potential of tomato powder. The objectives of the study are as follow:

- to evaluate the antioxidant effect and specific amount of tomato powder that would effectively reduce lipid oxidation in a specified quantity of broiler meat;

- to determine the effect of tomato powder on the sensory characteristics of broiler meat.

\section{MATERIALS AND METHOD}

Fresh Tomatoes (Roma VF) were purchased from a local market within Ilorin Metropolis. The tomato juice was extracted manually while the pericarp (flesh) excluding the seed was oven dried at $40^{\circ} \mathrm{C}$ for 48 hours. The oven-dried tomato was ground into powder using an electronic mixer blender (MC-999, England). Broiler chickens of eight weeks old were purchased from Unique farms, Ilorin Kwara State. The chickens were slaughtered by cutting through their jugular vein and de-feathered manually by dipping into hot water. Thereafter, the chickens were washed and eviscerated. The carcass was cut into different parts. The head, neck, legs, wings and the internal organs were removed, while the remaining parts were de-boned and deskinned. Thereafter, the meat was minced using a food processor (National MK$5080 \mathrm{M}$, England). The minced meat was weighed into $200 \mathrm{~g}$ portions. Tomato powder was applied to a separate $200 \mathrm{~g}$ of meat sample at the levels of $0 \%$ (control), $0.5 \%, 1 \%$ and $1.5 \%$ of the weight of the minced meat. $0.15 \%$ of Butylated Hydroxyl Anisole (BHA) was applied to a separate $200 \mathrm{~g}$ of meat and this served as positive control. Each $200 \mathrm{~g}$ of meat was divided into 16 parts of $12.5 \mathrm{~g}$ each. Eight (8) of these were cooked for $1^{1} / 2$ minutes using a microwave oven (National NN 5557 WF, China), while the other eight parts were left raw. The cooked and raw samples were stored in a refrigerator (ICHIBAN RF-5D1, Nigeria) for six and nine days, respectively. The refrigerator temperature was set at $4^{0} \mathrm{C}$. Oxidative stability of the cooked samples was monitored at two-day intervals while that of raw samples was monitored at three-day intervals.

\section{DETERMINATION OF LIPID OXIDATION}

Lipid oxidation in the samples was evaluated using the 2-thiobarbituric acid (TBA) assay [20]. The 2-thiobarbituric acid reactive substance (TBARS) values were expressed in milligram per malonaldehyde per kilogram of meat samples (mg $/ \mathrm{MDA} / \mathrm{kg}$ meat). Each treatment was replicated three times. To carry out the TBA test, $10 \mathrm{~g}$ of the meat sample was homogenized with $47.5 \mathrm{ml}$ of distilled water in a specimen bottle using glass pestle. The homogenized mixture was rinsed with $50 \mathrm{ml}$ of distilled water into a round bottom flask. Thereafter, $2.5 \mathrm{ml}$ of Hydrochloric acid (1:2 solution $\mathrm{v} / \mathrm{v}$ ) was added and the mixture was distilled through a condensing assembly to collect about $15 \mathrm{ml}$ of the distillate. The distillate $(5 \mathrm{ml})$ was mixed with $5 \mathrm{ml}$ of TBA (0.02M) and boiled for 35 minutes in water, then cooled for ten minutes with 
cold tap water for color development. The absorbance readings for duplicate samples and blank that contained $5 \mathrm{ml}$ of hydrochloric acid solution and $5 \mathrm{ml}$ of thiobarbituric acid (TBA) reagent were measured at $538 \mathrm{~nm}$ using a spectrophotometer (CECIL2000, England). The absorbance values were multiplied by a factor of 7.8 to obtain the Thiobarbituric Acid Reactive Substance (TBARS) values in milligram per malonaldehyde per kilogram of sample (mg/MDA $/ \mathrm{kg})$.

\section{SENSORY EVALUATION OF BROILER MEAT}

A forty-member panel comprised of staff and students of Faculty of Agriculture, University of Ilorin, Nigeria constituted the taste panel (assessors). They were invited in groups of ten for each storage day and were instructed on the parameters to adjudge, using a five-point Hedonic scale. Each panelist was served $5 \mathrm{~g}$ of each of the treated meat samples to taste. The raw samples were cooked in a microwave oven for one and half minutes before serving, while the cooked samples were re-warmed for 30 seconds using a microwave oven (National NN 5557 WF, China). Water was provided for each panelist to rinse his/her mouth after each bite to eliminate the taste of the previous meat sample.

\section{STATISTICAL ANALYSIS:}

The experiment followed a $5 * 2 * 4$ factorial arrangement in a completely randomized design. The data obtained were analyzed using analysis of the variance model suitable for the design with the aid of Genstat 5 program package [21]. Duncan multiple range test was used to determine differences between means. Significance was defined at $\mathrm{P}$ $<0.05$.

\section{RESULTS AND DISCUSSION}

The cooked meat samples were observed to have higher TBARS value (4.43) than the raw samples (2.31) as shown in Table 1. The reason might be that cooking activated some lypolytic enzymes such as lipase and phospholipase in the meat, which promoted lipid oxidation [22]. Another reason for the high TBARS value observed in the cooked samples might be the denaturation of the antioxidant compounds due to increase in temperature associated with cooking. It was reported that increase in cooking temperature of meat, results in decrease in the moisture content and increase in the fat content of the cooked meat thus increasing the rate of oxidative rancidity [23]. Other studies suggest that cooking disrupts the lipid membrane system, causing interaction of molecules such as oxygen and molecular weight metal with unsaturated fatty acids resulting in the generation of oxidative reactions [24, 25]. This result, however, contradicts the reports given by some authors who asserted that cooked pork patties have lower TBARS value than raw pork patties due to the formation of Maillard Reaction Products (MRPs) during cooking [4]. Maillard reaction products have been shown to have antioxidant activity $[4,10,13]$. It was further reported that the mechanism for antioxidant activity of MRPs is that they reduce hydroperoxides into products that are unable to form free radicals and inactivate free radicals that were formed during oxidative degradation of unsaturated fatty acids $[4,10,13,26]$. Main effect of antioxidant treatments was evaluated irrespective of the state of meat and storage days (Table 1). The control samples were observed to be readily

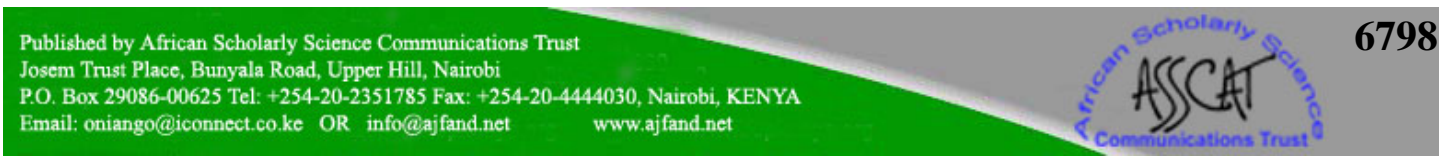


susceptible to lipid oxidation with the highest TBARS value of 4.43; this was followed by samples containing BHA. The addition of $0.5 \%, 1 \%$ and $1.5 \%$ tomato powder incurred a significant reduction $(\mathrm{P}<0.05)$ in lipid oxidation over those containing BHA. This shows that tomato powder is more potent than BHA, which has been reported to be effective in suppressing lipid oxidation in meat [11]. Apparently, oxidation of fat is enhanced in the presence of certain catalytic factors such as special metallic ions or salts but the process is slowed down or inhibited by antioxidants [15]. The low TBARS value obtained with $1.5 \%$ tomato powder is in accordance with the report, which states that the higher the amounts of antioxidant present in a medium, the lower the rate of lipid oxidation, and all things being equal [15].

Interactive effects of antioxidant treatments and storage days on the oxidative stability of cooked meat samples were shown in Table 2. It was observed that as the storage days increased, lipid oxidation increased. This may be caused by the increase in the formation of pro-oxidant compounds such as peroxides that eventually led to increment in lipid oxidation. At storage day zero, $0.5 \%$ tomato powder had the lowest TBARS value of 1.05. This was not significantly different from the TBARS value of $1 \%, 1.5 \%$ and BHA, which were 1.90, 2.14 and 2.03, respectively. At storage day two and day four, BHA had the lowest TBARS value of 2.76 and 4.23, respectively. However, there was no significant difference $(\mathrm{P}>0.05)$ between these values and those obtained for $0.5 \%$ tomato powder, which were 3.56 and 5.83, respectively. At storage day six, $1.5 \%$ tomato powder had the lowest TBARS value of 3.43 , which was not significantly different from that of BHA that was 3.69. This clearly confirms the capability of tomato powder to reduce lipid oxidation.

Interactive effects of graded levels of tomato powder and storage days in raw meat samples were shown in Table 3. At day 0, all levels of tomato powder reduced lipid oxidation more $(\mathrm{P}<0.05)$ than the control treatment. $0.5 \%$ tomato powder had the lowest TBARS value of 0.18 , which was significantly different $(\mathrm{P}<0.05)$ from that of other treatments. At storage day three, $1.5 \%$ tomato powder performed better than other treatments. There was no significant difference in the antioxidant potency of $0.5 \%, 1 \%$ and BHA. At storage day six, $1.5 \%$ tomato powder had the lowest TBARS value of 1.82, which was significantly different from that of other treatments. Butylated Hydroxyl Anisole, $0.5 \%$ and $1 \%$ tomato powder were equally effective at day six. The profound influence of tomato powder in reducing lipid oxidation is probably brought about by the presence of lycopene and glutathione in the tomato powder both of which are natural antioxidants $[10,15,19]$. These natural antioxidants can react with peroxyl or alkoxyl radicals, terminate the chain reaction of peroxidation by scavenging chain-propagating radicals, and thus suppress lipid oxidation [19].

The TBARS values of meat samples resulting from the interactive effects of antioxidant treatments and state of meat were shown in Table 4. It was observed that BHA reduced lipid oxidation more $(\mathrm{P}<0.05)$ in cooked meat samples. Although BHA had the lowest TBARS value of 3.18 , this was not significantly different $(\mathrm{P}>0.05)$ from the value obtained with $0.5 \%$ tomato powder, which was 3.72. Tomato powder at $1 \%$ and $1.5 \%$ had high TBARS value of 4.55 and 4.82 , respectively. The reason for 
these high values might be due to the formation of pro-oxidant compounds during heat treatment. Short heat treatment promotes initial reduction in the chain breaking activity of tomato juice. However, a recovery of activity was reported after prolong heat treatment [19]. In raw meat samples, all levels of tomato powder reduced lipid oxidation more $(\mathrm{P}<0.05)$ than BHA. The high TBARS value for BHA is unexpected and this could not be explained. Butylated hydroxyl anisole has been widely reported to be an active synthetic antioxidant [3, 4, 9, 27].

Sensory scores resulting from the interactive effects of antioxidant treatments and storage days on the sensory characteristics of cooked (re-warmed) meat samples were shown in Table 5 . In all the treated meat samples, panelists ranked meat samples tasted at storage days 2,4 , and 6 as having more $(\mathrm{P}<0.05)$ desirable color, and being juicier than meat samples tasted at storage day 0 . The reason for this is likely that as storage days progress, there was enough time for the applied treatments to react with the meat samples, thereby giving room to exact their characteristic effects, thus improving the juiciness and characteristic color of the meat samples. However, this result is contrary to the report, which asserts that freshly processed meat exhibits more juiciness and has a preferred color than that stored under refrigerated or freezing condition because cold storage does not enhance food quality, but rather it leads to mineral loss and reduction in the protein quality especially for long-term storage [28]. In addition, it was reported that cold storage has detrimental effect on the texture of meat if carried out rapidly, while the meat is still in the pre-rigor state [28]. Other studies suggest that deterioration of fresh chilled meat is due to surface changes because the natural surface of meat consists of fat and connective tissue and during cooling, the consistency of the latter changes so that further loss of water by evaporation is enhanced $[10,13]$. For flavor, in all the treated samples, meat samples tasted at storage day 0 were rated best by panelists than those tasted at other storage days. Meat samples tasted at storage days 2, 4, and 6 were said to have a sharp flavor. This was because as storage days increase, there was increase in the rate of lipid oxidation, which leads to warmed over flavor or oxidative rancidity. All tomato powder treated samples were scored higher than control and BHA treated samples. This agrees with the report that natural antioxidants are not only capable of enhancing the bland flavor of turkey meat, but also have a stabilizing effect on the flavor of the meat $[29,30]$. With respect to tenderness, in all treatment levels except control, meat samples tasted at storage day 2 were more $(\mathrm{P}<0.05)$ tender than those tasted at storage days 0 , 4, and 6 . Meat samples tasted at storage days 0 , 4, and 6 were said to have the same tenderness. For the overall acceptability, $0.5 \%, 1 \%$, and $1.5 \%$ tomato powders are ranked higher at all storage days than control and BHA. However, $1.5 \%$ tomato powder had the highest score. This clearly shows the capacity of tomato powder to enhance the sensory characteristics of broiler meat.

Table 6 showed the interactive effects of graded levels of antioxidant treatments and storage days on the sensory features of raw (recently cooked) broiler meat. In all antioxidant treatments, panelists ranked meat samples tasted at storage days 3, 6 and 9 as having a better color and being juicier than those tasted at storage day 0 . This is in agreement with values of the cooked (re-warmed) meat samples. Tomato powder at $0.5 \%, 1 \%$, and $1.5 \%$ treated samples were scored higher and said to have a better 
$(\mathrm{P}<0.05)$ color than control and BHA treated samples. For flavor, panelists ranked tomato powder treated samples as having the same flavor but different from that of control and BHA samples at all storage days. With respect to tenderness, for all antioxidant treatments, panelists rated meat samples tasted at day 9 to be more tender than those tasted on other storage days. The overall acceptability of all antioxidant treatments except BHA at all storage days were not significantly different $(\mathrm{P}>0.05)$. However, the overall acceptability of $1.5 \%$ tomato powder was the highest, thus, confirming the potency of tomato powder, not only as an antioxidant, but also a promoter of sensory characteristics of broiler meat.

\section{CONCLUSION AND RECOMMENDATIONS}

Addition of tomato powder to broiler meat effectively reduced lipid oxidation in raw and cooked samples compared to the control. It was also observed that $1.5 \%$ tomato powder was better than BHA in raw meat samples, while $0.5 \%$ tomato powder was more effective than BHA in cooked meat samples. Tomato powder improves the sensory characteristics of broiler meat. The use of tomato powder as antioxidant in broiler meat is highly recommended. Storage of meat in raw state is also recommended. 
Table 1: Main effects of antioxidant treatments and state of meat on oxidative stability of broiler meat

\begin{tabular}{|c|c|c|c|c|c|}
\hline Factor & \multicolumn{5}{|c|}{ TBARS (mg/MDA/kg) } \\
\hline \multirow[t]{2}{*}{ Antioxidant treatments } & $0 \%$ & $0.5 \%$ & $1 \%$ & $1.5 \%$ & BHA \\
\hline & $4.43^{b}$ & $3.02^{\mathrm{a}}$ & $3.00^{\mathrm{a}}$ & $2.92^{\mathrm{a}}$ & $3.49^{\mathrm{a}}$ \\
\hline SE & \multicolumn{5}{|l|}{0.154} \\
\hline \multirow{2}{*}{ State of meat } & \multicolumn{2}{|c|}{ Cooked } & \multicolumn{2}{|l|}{ Raw } & \\
\hline & \multicolumn{2}{|c|}{$4.43^{\mathrm{b}}$} & \multicolumn{2}{|l|}{$2.31^{\mathrm{a}}$} & \\
\hline SE & \multicolumn{5}{|l|}{0.079} \\
\hline
\end{tabular}

Table 2: Interactive effect of antioxidant treatments and storage days on oxidative stability of cooked broiler meat

\begin{tabular}{l}
\hline \multirow{2}{*}{$\begin{array}{l}\text { Antioxidant } \\
\text { treatments }\end{array}$} \\
\cline { 2 - 5 }
\end{tabular}




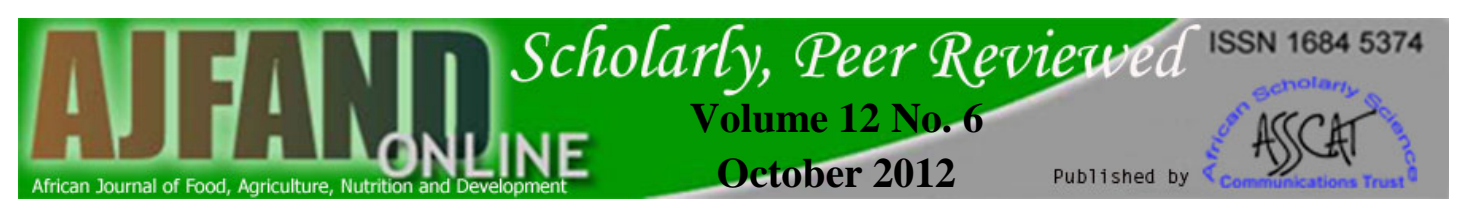

Table 3: Interactive effect of antioxidant treatments and storage days on oxidative stability of raw broiler meat

\begin{tabular}{|l|l|l|l|l|}
\hline \multirow{2}{*}{$\begin{array}{l}\text { Antioxidant } \\
\text { treatments }\end{array}$} & \multicolumn{4}{|c|}{ TBARS (mg/MDA/kg) } \\
\cline { 2 - 5 } & \multicolumn{4}{|c|}{ Storage days } \\
\cline { 2 - 5 } & 0 & 3 & 6 & 9 \\
\hline $0.5 \%$ & $2.47^{\mathrm{ab}}$ & $3.21^{\mathrm{c}}$ & $3.08^{\mathrm{c}}$ & $3.08^{\mathrm{b}}$ \\
\hline $1 \%$ & $0.18_{\mathrm{x}}{ }^{\mathrm{a}}$ & $2.83_{\mathrm{y}}{ }^{\mathrm{b}}$ & $2.75_{\mathrm{y}}{ }^{\mathrm{b}}$ & $3.38_{\mathrm{y}}{ }^{\mathrm{b}}$ \\
\hline $1.5 \%$ & $1.66_{\mathrm{x}}{ }^{\mathrm{a}}$ & $1.79_{\mathrm{x}}{ }^{\mathrm{a}}$ & $2.47_{\mathrm{y}}{ }^{\mathrm{b}}$ & $1.30_{\mathrm{x}}{ }^{\mathrm{a}}$ \\
\hline BHA & $1.99_{\mathrm{y}}{ }^{\mathrm{a}}$ & $0.83_{\mathrm{x}}{ }^{\mathrm{a}}$ & $1.82_{\mathrm{y}}{ }^{\mathrm{a}}$ & $1.30_{\mathrm{y}}{ }^{\mathrm{a}}$ \\
\hline SE & $2.21_{\mathrm{x}}{ }^{\mathrm{a}}$ & $2.63_{\mathrm{x}}{ }^{\mathrm{b}}$ & $2.45_{\mathrm{x}}{ }^{\mathrm{b}}$ & $3.35_{\mathrm{y}}{ }^{\mathrm{b}}$ \\
\hline
\end{tabular}

a, b, c means having different superscripts along the same column are significantly different $(\mathrm{P}<0.05)$. $x, y, z$ means having different subscripts along the same row are significantly different.

Table 4: Interactive effect of antioxidant treatments and state of meat on oxidative stability of broiler meat

\begin{tabular}{|l|l|l|l|l|l|}
\hline \multirow{3}{*}{ State of meat } & \multicolumn{5}{|c|}{ TBARS (mg/MDA/kg) } \\
\cline { 2 - 6 } & \multicolumn{4}{|c|}{ Antioxidant treatments } \\
\cline { 2 - 6 } & $0 \%$ & $0.5 \%$ & $1 \%$ & $1.5 \%$ & BHA \\
\hline Cooked & $2.96^{\mathrm{bc}}$ & $2.28^{\mathrm{b}}$ & $2.16^{\mathrm{b}}$ & $1.49^{\mathrm{a}}$ & $3.66^{\mathrm{c}}$ \\
\hline Raw & $5.89^{\mathrm{c}}$ & $3.72^{\mathrm{a}}$ & $4.55^{\mathrm{b}}$ & $4.82^{\mathrm{b}}$ & $3.18^{\mathrm{a}}$ \\
\hline SE & 0.152 & \multicolumn{4}{|c}{} \\
\hline
\end{tabular}

$\mathrm{a}, \mathrm{b}, \mathrm{c}$ means having different superscript along the same row are significantly different $(\mathrm{P}<0.05)$. 


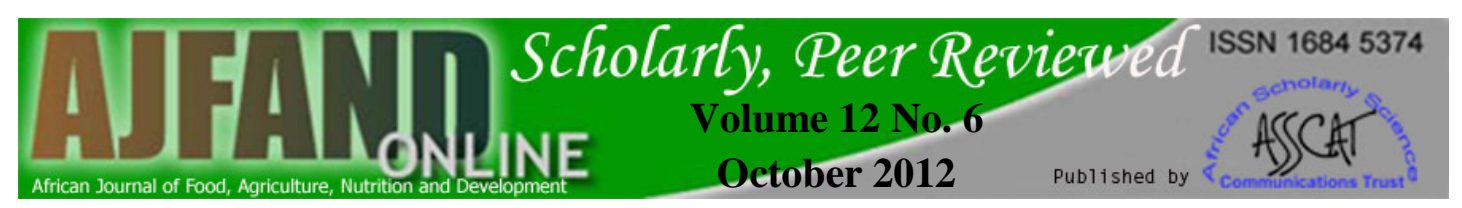

Table 5: Interactive effect of antioxidant treatment and storage days on sensory characteristics of raw (recently cooked) broiler meat

\begin{tabular}{|c|c|c|c|c|c|c|}
\hline \multirow[t]{2}{*}{ Antioxidant } & \multirow{2}{*}{$\begin{array}{l}\text { Storage } \\
\text { days }\end{array}$} & \multicolumn{5}{|c|}{ Sensory characteristics (Scores) } \\
\hline & & Colour & Flavor & Juiciness & Tenderness & $\begin{array}{l}\text { Overall } \\
\text { acceptability }\end{array}$ \\
\hline $0 \%$ & $\begin{array}{l}0 \\
3 \\
6 \\
9\end{array}$ & $\begin{array}{l}1.80^{\mathrm{a}} \\
2.00^{\mathrm{a}} \\
1.90^{\mathrm{a}} \\
2.20^{\mathrm{a}}\end{array}$ & $\begin{array}{l}2.20^{\mathrm{a}} \\
3.20^{\mathrm{b}} \\
2.80^{\mathrm{b}} \\
2.20^{\mathrm{a}}\end{array}$ & $\begin{array}{l}1.80^{\mathrm{a}} \\
1.40^{\mathrm{a}} \\
1.80^{\mathrm{a}} \\
2.00^{\mathrm{a}}\end{array}$ & $\begin{array}{l}1.40^{\mathrm{a}} \\
2.20^{\mathrm{a}} \\
2.20^{\mathrm{a}} \\
2.20^{\mathrm{a}}\end{array}$ & $\begin{array}{l}3.40^{\mathrm{b}} \\
2.80^{\mathrm{a}} \\
4.00^{\mathrm{c}} \\
2.80^{\mathrm{a}}\end{array}$ \\
\hline $0.5 \%$ & $\begin{array}{l}0 \\
3 \\
6 \\
9\end{array}$ & $\begin{array}{l}2.80^{\mathrm{b}} \\
3.00^{\mathrm{b}} \\
2.80^{\mathrm{b}} \\
2.60^{\mathrm{ab}}\end{array}$ & $\begin{array}{l}3.20^{\mathrm{b}} \\
3.60^{\mathrm{bc}} \\
3.20^{\mathrm{b}} \\
3.40^{\mathrm{b}}\end{array}$ & $\begin{array}{l}4.20^{\mathrm{C}} \\
4.00^{\mathrm{C}} \\
4.00^{\mathrm{C}} \\
4.00^{\mathrm{C}}\end{array}$ & $\begin{array}{l}2.40^{\mathrm{a}} \\
2.40^{\mathrm{a}} \\
3.60^{\mathrm{bc}} \\
2.80^{\mathrm{b}}\end{array}$ & $\begin{array}{l}4.40^{\mathrm{c}} \\
2.50^{\mathrm{a}} \\
2.40^{\mathrm{a}} \\
3.20^{\mathrm{b}}\end{array}$ \\
\hline $1 \%$ & $\begin{array}{l}0 \\
3 \\
6 \\
9\end{array}$ & $\begin{array}{l}2.60^{\mathrm{ab}} \\
3.00^{\mathrm{b}} \\
3.00^{\mathrm{b}} \\
3.40^{\mathrm{b}}\end{array}$ & $\begin{array}{l}3.60^{\mathrm{bc}} \\
3.60^{\mathrm{bc}} \\
2.80^{\mathrm{a}} \\
3.20^{\mathrm{b}}\end{array}$ & $\begin{array}{l}3.80^{\mathrm{bc}} \\
4.00^{\mathrm{c}} \\
3.80^{\mathrm{bc}} \\
3.80^{\mathrm{bc}}\end{array}$ & $\begin{array}{l}3.00^{\mathrm{b}} \\
3.00^{\mathrm{b}} \\
3.40^{\mathrm{b}} \\
3.60^{\mathrm{bc}}\end{array}$ & $\begin{array}{l}3.00^{\mathrm{b}} \\
3.60^{\mathrm{bc}} \\
3.60^{\mathrm{bc}} \\
3.00^{\mathrm{b}}\end{array}$ \\
\hline $1.5 \%$ & $\begin{array}{l}0 \\
3 \\
6 \\
9\end{array}$ & $\begin{array}{l}3.60^{\mathrm{bc}} \\
3.80^{\mathrm{bc}} \\
5.00^{\mathrm{c}} \\
4.60^{\mathrm{c}}\end{array}$ & $\begin{array}{l}3.60^{\mathrm{bc}} \\
4.60^{\mathrm{c}} \\
4.00^{\mathrm{c}} \\
4.40^{\mathrm{c}}\end{array}$ & $\begin{array}{l}4.60^{\mathrm{C}} \\
4.60^{\mathrm{C}} \\
4.40^{\mathrm{C}} \\
4.40^{\mathrm{C}}\end{array}$ & $\begin{array}{l}3.80^{\mathrm{bc}} \\
4.20^{\mathrm{c}} \\
3.20^{\mathrm{b}} \\
4.10^{\mathrm{c}}\end{array}$ & $\begin{array}{l}3.40^{\mathrm{b}} \\
3.20^{\mathrm{b}} \\
4.40^{\mathrm{c}} \\
4.40^{\mathrm{c}}\end{array}$ \\
\hline BHA & $\begin{array}{l}0 \\
3 \\
6 \\
9\end{array}$ & $\begin{array}{l}2.20^{\mathrm{a}} \\
2.40^{\mathrm{a}} \\
2.50^{\mathrm{a}} \\
2.50^{\mathrm{a}}\end{array}$ & $\begin{array}{l}3.20^{\mathrm{b}} \\
2.70^{\mathrm{a}} \\
2.40^{\mathrm{a}} \\
4.32^{\mathrm{c}}\end{array}$ & $\begin{array}{l}3.20^{\mathrm{b}} \\
3.20^{\mathrm{b}} \\
3.10^{\mathrm{b}} \\
3.50^{\mathrm{bc}}\end{array}$ & $\begin{array}{l}2.10^{\mathrm{a}} \\
1.85^{\mathrm{a}} \\
1.60^{\mathrm{a}} \\
2.20^{\mathrm{a}}\end{array}$ & $\begin{array}{l}1.60^{\mathrm{a}} \\
1.60^{\mathrm{a}} \\
2.00^{\mathrm{a}} \\
2.40^{\mathrm{a}}\end{array}$ \\
\hline
\end{tabular}

a, b, c means having different superscript along the same column are significantly different $(\mathrm{P}<0.05)$ 


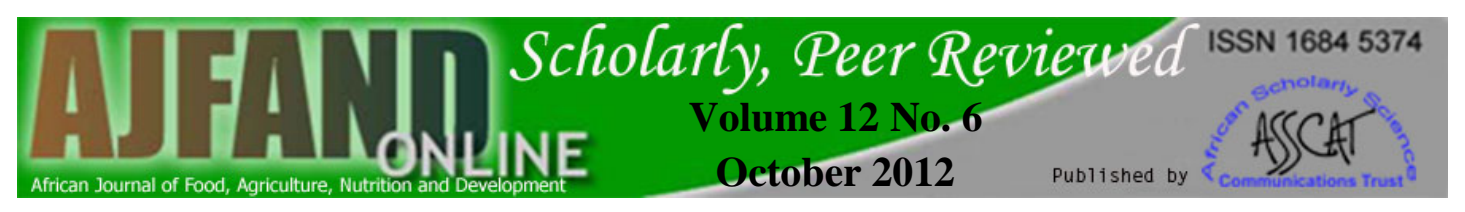

Table 6: Interactive effect of antioxidant treatment and storage days on sensory characteristics of cooked (re-warmed) broiler meat

\begin{tabular}{|c|c|c|c|c|c|c|}
\hline \multirow[t]{2}{*}{ Antioxidant } & \multirow{2}{*}{$\begin{array}{l}\text { Storage } \\
\text { days }\end{array}$} & \multicolumn{5}{|c|}{ Sensory characteristics (Scores) } \\
\hline & & Colour & Flavor & Juiciness & Tenderness & $\begin{array}{l}\text { Overall } \\
\text { acceptability }\end{array}$ \\
\hline $0 \%$ & $\begin{array}{l}0 \\
2 \\
4 \\
6\end{array}$ & $\begin{array}{l}1.60^{\mathrm{a}} \\
1.60^{\mathrm{a}} \\
1.60^{\mathrm{a}} \\
1.60^{\mathrm{a}}\end{array}$ & $\begin{array}{l}2.60^{\mathrm{a}} \\
2.60^{\mathrm{a}} \\
2.00^{\mathrm{a}} \\
2.20^{\mathrm{a}}\end{array}$ & $\begin{array}{l}1.80^{\mathrm{a}} \\
1.40^{\mathrm{a}} \\
1.80^{\mathrm{a}} \\
2.00^{\mathrm{a}}\end{array}$ & $\begin{array}{l}1.80^{\mathrm{a}} \\
1.80^{\mathrm{a}} \\
1.80^{\mathrm{a}} \\
2.00^{\mathrm{a}}\end{array}$ & $\begin{array}{l}2.40^{\mathrm{a}} \\
3.00_{\mathrm{b}} \\
2.60^{\mathrm{a}} \\
3.20^{\mathrm{b}}\end{array}$ \\
\hline $0.5 \%$ & $\begin{array}{l}0 \\
2 \\
4 \\
6\end{array}$ & $\begin{array}{l}2.40^{\mathrm{a}} \\
3.60^{\mathrm{bc}} \\
2.30^{\mathrm{a}} \\
3.00^{\mathrm{b}}\end{array}$ & $\begin{array}{l}3.20^{\mathrm{b}} \\
3.00^{\mathrm{b}} \\
2.50^{\mathrm{a}} \\
3.00^{\mathrm{b}}\end{array}$ & $\begin{array}{l}3.00^{\mathrm{b}} \\
3.40^{\mathrm{b}} \\
1.80^{\mathrm{a}} \\
3.10^{\mathrm{b}}\end{array}$ & $\begin{array}{l}2.40^{\mathrm{a}} \\
3.20^{\mathrm{b}} \\
3.00^{\mathrm{b}} \\
2.50^{\mathrm{a}}\end{array}$ & $\begin{array}{l}2.30^{\mathrm{a}} \\
2.60^{\mathrm{a}} \\
2.20^{\mathrm{a}} \\
2.00^{\mathrm{a}}\end{array}$ \\
\hline $1 \%$ & $\begin{array}{l}0 \\
2 \\
4 \\
6\end{array}$ & $\begin{array}{l}2.60^{\mathrm{a}} \\
3.60^{\mathrm{bc}} \\
2.80^{\mathrm{a}} \\
3.40^{\mathrm{b}}\end{array}$ & $\begin{array}{l}3.60^{\mathrm{bc}} \\
3.00^{\mathrm{b}} \\
3.00^{\mathrm{b}} \\
3.60^{\mathrm{bc}}\end{array}$ & $\begin{array}{l}3.60^{\mathrm{bc}} \\
3.20^{\mathrm{b}} \\
3.40^{\mathrm{b}} \\
3.40^{\mathrm{b}}\end{array}$ & $\begin{array}{l}3.20^{\mathrm{b}} \\
3.40^{\mathrm{b}} \\
3.40^{\mathrm{b}} \\
3.60^{\mathrm{bc}}\end{array}$ & $\begin{array}{l}2.60^{\mathrm{a}} \\
2.60^{\mathrm{a}} \\
3.00^{\mathrm{b}} \\
2.60^{\mathrm{a}}\end{array}$ \\
\hline $1.5 \%$ & $\begin{array}{l}0 \\
2 \\
4 \\
6\end{array}$ & $\begin{array}{l}4.00^{\mathrm{C}} \\
4.40^{\mathrm{C}} \\
4.40^{\mathrm{C}} \\
4.20^{\mathrm{C}}\end{array}$ & $\begin{array}{l}4.00^{\mathrm{c}} \\
3.40^{\mathrm{b}} \\
3.80^{\mathrm{bc}} \\
4.20^{\mathrm{c}}\end{array}$ & $\begin{array}{l}3.40^{\mathrm{b}} \\
3.40^{\mathrm{b}} \\
3.60^{\mathrm{bc}} \\
3.00^{\mathrm{b}}\end{array}$ & $\begin{array}{l}3.80^{\mathrm{bc}} \\
4.00^{\mathrm{c}} \\
2.20^{\mathrm{c}} \\
2.60^{\mathrm{a}}\end{array}$ & $\begin{array}{l}3.60^{\mathrm{bc}} \\
4.40^{\mathrm{c}} \\
3.40^{\mathrm{b}} \\
2.80^{\mathrm{a}}\end{array}$ \\
\hline BHA & $\begin{array}{l}0 \\
2 \\
4 \\
6\end{array}$ & $\begin{array}{l}2.00^{\mathrm{a}} \\
2.00^{\mathrm{a}} \\
2.40^{\mathrm{a}} \\
3.00^{\mathrm{b}}\end{array}$ & $\begin{array}{l}3.00^{\mathrm{b}} \\
2.00^{\mathrm{a}} \\
2.20^{\mathrm{a}} \\
2.40^{\mathrm{a}}\end{array}$ & $\begin{array}{l}3.20^{\mathrm{b}} \\
3.20^{\mathrm{b}} \\
3.30^{\mathrm{b}} \\
3.30^{\mathrm{b}}\end{array}$ & $\begin{array}{l}1.60^{\mathrm{a}} \\
2.00^{\mathrm{a}} \\
2.00^{\mathrm{a}} \\
2.40^{\mathrm{a}}\end{array}$ & $\begin{array}{l}2.10^{\mathrm{a}} \\
2.20^{\mathrm{a}} \\
2.20^{\mathrm{a}} \\
2.20^{\mathrm{a}}\end{array}$ \\
\hline
\end{tabular}

a, b, c means having different superscript along the same column are significantly different $(\mathrm{P}<0.05)$

Table 7: Sensory Score sheet (5-point hedonic scale)

\begin{tabular}{|c|c|c|c|c|c|}
\hline Sensory & \multicolumn{5}{|c|}{ Sensory scores } \\
\hline & 1 & 2 & 3 & 4 & 5 \\
\hline Color & $\begin{array}{l}\text { Dislike } \\
\text { extremely }\end{array}$ & $\begin{array}{l}\text { Dislike } \\
\text { moderately }\end{array}$ & $\begin{array}{l}\text { Neither like nor } \\
\text { dislike }\end{array}$ & $\begin{array}{l}\text { Like } \\
\text { moderately }\end{array}$ & $\begin{array}{l}\text { Like } \\
\text { extremely }\end{array}$ \\
\hline Flavor & $\begin{array}{l}\text { Dislike } \\
\text { extremely }\end{array}$ & $\begin{array}{l}\text { Dislike } \\
\text { moderately }\end{array}$ & $\begin{array}{l}\text { Neither like nor } \\
\text { dislike }\end{array}$ & $\begin{array}{l}\text { Like } \\
\text { moderately }\end{array}$ & $\begin{array}{l}\text { Like } \\
\text { extremely }\end{array}$ \\
\hline Juiciness & Extremely dry & Slightly dry & Slightly juicy & $\begin{array}{l}\text { Moderately } \\
\text { juicy }\end{array}$ & $\begin{array}{l}\text { Extremely } \\
\text { juicy }\end{array}$ \\
\hline Tenderness & Very tough & Slightly tough & Slightly tender & $\begin{array}{l}\text { Moderately } \\
\text { tender }\end{array}$ & $\begin{array}{l}\text { Extremely } \\
\text { tender }\end{array}$ \\
\hline $\begin{array}{l}\text { Overall } \\
\text { acceptability }\end{array}$ & $\begin{array}{l}\text { Dislike } \\
\text { extremely }\end{array}$ & $\begin{array}{l}\text { Dislike } \\
\text { moderately }\end{array}$ & $\begin{array}{l}\text { Neither like nor } \\
\text { dislike }\end{array}$ & $\begin{array}{l}\text { Like } \\
\text { moderately }\end{array}$ & $\begin{array}{l}\text { Like } \\
\text { extremely }\end{array}$ \\
\hline
\end{tabular}




\section{REFERENCES}

1. Lodikas D and V Lougoyos Lipid oxidation in Muscle foods. A review of food chem. 1990; 35:295-314.

2. Mortran DS Lipid oxidation and flavor in meat and meat products. Food Sci Techno Today 1987; 1:159-162.

3. Buckley DJ, Morrisay PA and JI Gray Influence of dietary vitamin E on the oxidative stability and quality of pig meat. J.Anim.Sci .1995; 73:31223130 .

4. Olorunsanya OA, Olorunsanya EO, Akanbi AS and RMO Kayode Antioxidant properties of rice husk extract in raw and cooked pork patties. $J$. Applied Agricultural research. 2009 1:143-14718.

5. Chen CC, Pearson AM, Gray JL, Foolad MH and P Ku Some factors Influencing the non heam iron content of meat and its implication in oxidation. J. Food Sci. 1984; 49: 581-584.

6. Moure A, Cruz JM, Franco D, Dominguez JM, Sineiro J, Nunez MJ and JC Parajo. Natural antioxidants from residual sources. J. food chem. 2000; 72:145-146.

7. Onyeneho SN and NS Heittiarachchy Effect of navy bean hull extract on the oxidative stability of Soy and Sunflower oils. J. Agric. Food chem. 1991; 39:1701-1704.

8. Wilson BR, Pearson AM and FB Shorthand Effect of total lipids and phospholipids on warmed-over flavor in red and white muscles from several species a measured by TBA analysis. J. Agric. Food chem. 1976; 24:7-11.

9. Chastein ME, Hauffman DL, Hseich WIH and JC Cordray Antioxidant in restructured beef/pork steaks. J. Food Sci.1982; 47:1779-1782.

10. Salih AM, Price JF, Smith DM and LE Dawson Lipid degradation in turkey breast meat during cooking and storage. J. Poultry Sci. 1989;68:754-761.

11. Kahl $\mathbf{R}$ and $\mathbf{H}$ Kappus Toxicology of synthetic antioxidants BHA \& BHT in comparison with natural antioxidant Vitamin C. zeitschrift-fuer LebesmittelUntersuchung-and-Forshung 1993; 196: 329-338.

12. Cao G, Sofic E and RL Prior Antioxidant and Pro-oxidant behavior of flavonoids: Structure-activity relationship. Free Radical Biology \& Medicine. 1997; 22:740-741.

13. Bailey ME Inhibition of warmed-over flavor with emphasis on Maillard reaction products. Food Techno. 1988; 42:123. 
14. Abdallah AE and JP Roozen Effect of plant extracts on the oxidative stability of sunflower oil and emulsion. J. Agric. Food Chem. 1999; 64: 323329.

15. Lisa $\mathbf{T}$ The top 10 Antioxidant foods. Back to Nutrition Archives. Better nutrition, Jan 2002; pp 1-3.

16. Porkony J Natural antioxidant for food use. Trends food Sci Techno. 1991; 2:222-226.

17. Gray SS, Gomnae EA and DJ Buckley Oxidative quality and shelf life of meat. J. of meat Sci. 1996; 42:127-132.

18. Shahidi F and PD Wanasundara Phenolic antioxidants. Critical Reviews in Food Sci. Nutrition. 1992; 32: 1, 62-103.

19. Anese M, Manzacco L, Nicoli MC and CR Lerici Antioxidant properties of tomato juice as affected by Heating. J. Food Sci. Agric. 1999; 79:750-754.

20. Tarladgris BG, Pearson AM and LR Dungan Chemistry of 2- TBA test for determination of oxidative Rancidity in foods and formation of TBA malonaldehyde complex without acid heat treatment. J. Sci, Food. Agric.1964; 15:607-620.

21. Payne RW, Lane PW and Genstat 5 committes Genstat 5 reference manual 1987; London Oxford Science Publications.

22. Krinsky NI Plant carotenoids and related molecules: important dietary antioxidants. In proceeding of Biochemical society symposium 1994;No 61. Ed by Rice-Evans C, Halliwell, BB and GG Lunt . Portland Press London, UK pp 117-126.

23. Smith GC, Cross HR, Carpenter ZL, Murphy CE, Savell JW, Abraham HC and GW Davos Relationship of USDA maturity groups to palatability of cooked beef. J. Food Sci 1982; 2: 47-50.

24. Tims MJ and BM Watts Protections of cooked meat with phosphate. Food Techno.1958; 12:240-243.

25. Asghar A, Gray JL, Buckley DJ, Pearson AM and AM Booren Perspectives in warmed-over flavor. Food Techno 1988; 42 (6):102-108.

26. Guntersperger B, Hammerli-Meier DE and FE Echer Rosemary extract and precooking effects on lipid oxidation in heat stabilized meat. J Food Sci. 1998; 63:95.

27. Olorunsanya OA, Olorunsanya EO, Aliu OT and RMO Kayode Effects of different species of pepper on the oxidative Stability of raw and cooked Pork parties. Pakistan J. Nutrition 2009; 8 (10):1588-5194. 


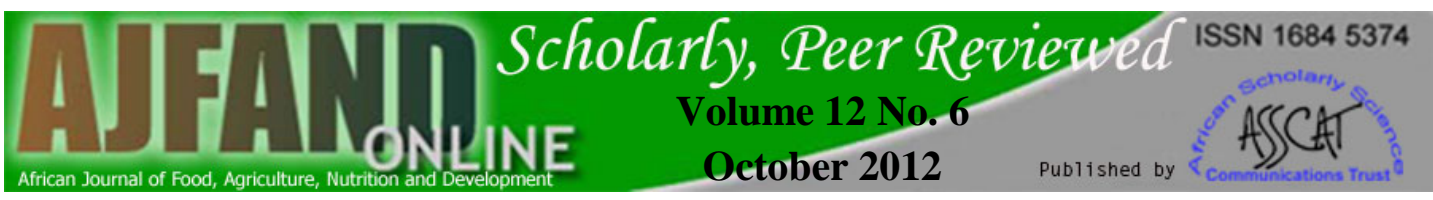

28. Pikul JD, Leszynsk E, Bechitel PJ and FA Kumerows Effect of frozen storage and cooking on lipids in chicken meat. J Food Sci.1984; 49:838-843.

29. Annie JK and $\mathbf{Z}$ Gideon Tomato pomace may be a good source of vitamin $\mathbf{E}$ in Broiler diets. California Agriculture. 2004; Vol 58, No 1 pp 59.

30. Sato K, Hegarty GR and HK Herring The inhibition of warmed over flavor in cooked meat. J Food Sci. 1973; 38:398-403. 